
\title{
25 Research Soure \\ Episodes of Violence Suffered by Migrants Transiting Through Libya: A Cross-Sectional Study in a Reception and Healthcare Centre
}

laura reques ( $\square$ requeslaura@hotmail.com )

Medecins du Monde France https://orcid.org/0000-0003-1589-8012

E Aranda-Fernandez

Medecins du Monde France

C Rolland

Medecins du Monde France

A Grippon

Medecins du Monde France

C Reboul

Medecins du Monde France

N Godard

Medecins du Monde France

N Luhmann

Medecins du Monde France

\section{Short report}

Keywords: Migration, violence, Libya, healthcare access

Posted Date: January 16th, 2020

DOI: https://doi.org/10.21203/rs.2.20172/v2

License: (c) (i) This work is licensed under a Creative Commons Attribution 4.0 International License.

Read Full License

Version of Record: A version of this preprint was published at Conflict and Health on February 28th, 2020. See the published version at https://doi.org/10.1186/s13031-020-0256-3. 


\section{Abstract}

Introduction: The Central Mediterranean Route, passing through Libya, is one of the most dangerous for migrants. Episodes of violence have been documented but have not been accurately quantified. The objective of the study was to estimate the prevalence of episodes of violence suffered in Libya by migrants consulting a Médecins du Monde reception and healthcare centre.

Methodology: Monocentric cross-sectional study. All migrants over the age of 18 years who had passed through Libya and arrived in Europe from 2017 during the recruitment period (February -May 2019). The presence of emotional distress was considered as an exclusion criterion.. The proportion, frequency and factors associated to physical, deprivation and sexual violence were estimated through a bespoken questionnaire, as well as healthcare access and psychosocial support needs.

Results: 98 people were recruited and 72 were interviewed (17 refused to participate and 9 were excluded). $76.4 \%$ were men, mean for the age was 31.9 years, $76.4 \%$ had low educational level, $66.7 \%$ came from Ivory Coast and $59.7 \%$ had left their country for security reasons. The median length of stay in Libya was 180 days. The overall proportion of participants having suffered from violence was $96.4 \%$ among men and $88.2 \%$ among women. The prevalence of physical, deprivation and sexual violence for men and women were $94.2 \%, 81.7 \%$ and $18 \%$ and $80.0 \%, 86.7 \%$ and $53.3 \%$, respectively. No other statistical differences were found. Access to healthcare in Libya was non-existent. $63.9 \%$ of participants were oriented to psychosocial support after the interview.

Conclusions: The vast majority of migrants report having been victims of violence during their transit through Libya. Women are at particular risk of sexual violence. Psychosocial support for this population is urgent.

\section{Background}

Several reports show that violence related to migration, including physical assault, torture and sexual violence, is a sad reality $(1-3)$. Among the migratory routes, the Central Mediterranean, which crosses Libya, is one of the most dangerous (2) .

Libya has been frequently indexed by the media for its migration policy and several international organisations have collected evidences and testimonies relating the violence suffered by migrants (4-6). Nevertheless, there are no scientific study which collected quantitative evidence on this subject.

The objective of this study was to quantify the episodes of violence according to their typology, to determine its associated factors, as well as to assess healthcare access and need for psychosocial support among migrants having transited Libya and visiting a Médecins du Monde (MdM) reception and healthcare centre.

\section{Methods}


The study was cross-sectional and monocentric. The target population was the beneficiaries of the MdM reception and healthcare centre in Paris. Individuals aged over 18 years old, with foreign nationality, having transited through Libya and having arrived in Europe from 2017 were included. Participants were excluded if they presented emotional distress, assessed by the Refugee Health Screener-15 (RHS-15) (7). Patients were recruited during the medical consultations and once they had consented to participate they passed to an isolated room where the survey was performed by an specialised doctor, who previously evaluated the exclusion criteria.

A sample size according to a prevalence of violence of $95 \%$, a margin of error of $5 \%$ and a confidence interval (Cl) of $95 \%$ was set to 72 individuals. Sampling was exhaustive until accomplishing the sample size.

The data collection tool was a bespoken online survey (KoboTool Box). Data were automatically added to a secure database. A two-weeks pre-test period was conducted in order to test the survey feasibility.

The study assessed two types of violence: direct and witnessed. In both cases, physical, sexual and deprivation violence episodes were tracked. Physical violence was divided in "episodes with firearms" (i.e. injury, aggression, shooting) and "episodes without firearms" (physical injury, beatings, threat). Sexual violence addressed "episodes of rape", deprivation violence included suffering from or witnessing "episodes of detention", "episodes of food deprivation", "episodes of confiscation", "episodes of racketeering", and "episodes of separation of family members". The frequency and the perpetrators of these episodes were also tracked. For the former it was set to "daily", "weekly", "less than once a week" or "very rare" and the latter was divided in "governmental forces", "armed groups", "civils" or "not identified". Healthcare access during the journey in Libya and need for psychosocial support after the interview were also assessed. Participants were oriented to specialised teams with their agreement.

The descriptive analysis for continuous variables used mean \pm standard deviation, median, interquartile range and T-student tests. Percentages with a 95\% confidence interval and Chi2 tests were used for categorical variables. Stata v.15 software was used for statistical analysis.

This study was conducted in compliance with the ethical principles of the Helsinki Declaration. All participants received a written information sheet, and their participation was voluntary after providing verbal informed consent. All information provided was anonymised and confidentiality was ensured. Psychosocial support was available throughout the interview for all participants.

\section{Main Findings}

98 people were recruited and 72 were interviewed from February to May 2019 (17 refused to participate and 9 were excluded).

Table 1 describes the population and the episodes for the different types of violence. 72 people were interviewed (55 men and 17 women). Mean age was 31.9 years old, $76.4 \%$ had primary studies, $66.6 \%$ 
came from Ivory Coast (followed by Mali $23.6 \%$ ) and $29.4 \%$ of women were pregnant at some stage of the journey. Mean length of stay in Libya was 180 days. Only $2.8 \%$ had access to healthcare. $63.9 \%$ of the participants looked for psychosocial support after the interview. Statistically significant differences by sex were found in the educational level $(p=0.03)$, type of travel $(p=0.01)$ and healthcare access $(p=0.05)$.

According to the episodes of direct and witnessed violence, results show that $94.4 \%$ of the participants suffered some type of violence ( $93.6 \%$ of men and $88.2 \%$ of women). $91.1 \%$ of participants suffered from physical violence (80.0\% of women and $94.3 \%$ of men). $89.5 \%$ of participants experienced violence with deprivation ( $81.7 \%$ of men and $86.7 \%$ of women) and $26.5 \%$ suffered sexual violence $(18.9 \%$ of men and $53.3 \%$ of women). $49.1 \%$ of men and $22.2 \%$ of women experienced forced labour. In addition, $17.6 \%$ of women had unsafe abortions during the journey. Differences by sex were statistically significant for physical, sexual violence and forced labour $(p<0.05)$.

$100 \%$ of participants witnessed some kind of violence, with $93.1 \%$ witnessing episodes of physical violence, $94.4 \%$ episodes of deprivation violence, $79.2 \%$ episodes of sexual violence and $88.2 \%$ other type of episodes of violence. No statistically significant differences by sex were found.

Table 2 describes episodes of physical, deprivation and sexual violence by sociodemographic characteristics and other secondary variables, showing no statistically significant differences in any of them.

In addition, related to the episodes of physical violence, $38 \%$ of participants reported daily violence, $48 \%$ weekly violence, $15 \%$ less than weekly and $5 \%$ rarely. These percentages were $37 \%, 54 \%, 9 \%$ and $0 \%$ and $41 \%, 25 \%, 34 \%$ and $0 \%$ for deprivation and sexual violence, respectively. In $54 \%$ of the cases perpetrators were not identified, $29 \%$ were civil, $10 \%$ armed groups and $7 \%$ governmental forces.

\section{Discussion}

Human rights' violations in Libya have been documented for years by international organizations, think tanks or journalists $(4,8-10)$. Nevertheless, these evidences come mainly from individual testimonies, reports or press releases. The added value of our study resides in its methodology, that enables to quantify the prevalence of this episodes in the general population of migrants hosted in a European country.

Our results show that the vast majority of people suffered from long imprisonment and confinement, where violence was systematic and of a huge magnitude. In most cases, the episodes of physical violence were suffered every day or almost every day and deprivation episodes lasted for the whole journey. In addition, perpetrators were very difficult to identify (more than a half of the participants simply called them "the Arabs").

It have been denounced by many NGOs that physical violence occurs mainly in places of confinement and is closely linked to the exploitation of migrants, forced labour and extortion $(4,11,12)$. Firearms are 
very common and often used for threat, but episodes of mass murders and shootings have also been documented. A number of reports mention that extortion is a common practice. However, NGOs note that migrants are often abducted by smugglers when they arrive in the country. They can be released if they pay, themselves or their families but they can also be sold to another smuggling group $(4,11)$.

In our study, women are particularly vulnerable to sexual violence. This has also been documented by other reports pointing that sexual violence is a common practice during the detentions or before being released (13-16). One third of the victims of sexual violence of the study stated that episodes were very common (daily or almost daily and by multiple perpetrators). The results of the study show that men are also exposed to sexual violence. Nevertheless, this type of violence might have been underestimated, especially for men, as the nature of the violence, which affects their privacy, sexuality and gender identity, makes it difficult to speak up.

As it has been shown in our study, access to healthcare in Libya is almost non-existent. Our study shows that any of the participants had ever been treated by a doctor or had received medication during their journey. It has been documented that the health system in Libya is collapsed and it is facing serious problems due to infrastructure damage, lack of medicines, medical equipment and staff (10) (17).

Most people asked for psychological support after the questionnaire, reflecting a real urgency. Literature has well document how mental health disorders occur as a consequence of migration, mainly linked to forced, unplanned, poorly planned or illegal migration, low educational level, isolation, lack of support and perceived discrimination (18-20).

\section{Limitations}

The profile of participants is restricted to the recruitment location, which affects the external validity. nevertheless, as there were no access barriers and this centre in one of the biggest and most popular for underprivileged people in France, results could apply for a larger population of undocumented migrants arriving in Europe. In addition, the refusal and exclusion linked to emotional distress could have avoided the most vulnerable individuals from participating, probably due to the difficulty of evoking traumatic events. Moreover, it is possible that sexual violence was underestimated, especially among men, as it was normally evoked as witnessed. Finally, the low proportion of women could also limit the statistical power for this group.

\section{Conclusions}

Violence in Libya is structural and systematic. Women are also very exposed to sexual violence. There is an almost total lack of healthcare access in Libya. It is urgent to develop a strategy to provide psychosocial and medical support to migrants suffering from violence.

\section{Declarations}




\section{Ethics approval and consent to participate}

This research project was approved by the INSERM Institutional Review Board (IRB). The study was conducted in compliance with the ethical principles of the Helsinki Declaration. All participants were informed of the study's objectives and design, and their participation was voluntary after providing verbal informed consent.

\section{Consent for publication}

Not applicable.

\section{Availability of data and materials}

The datasets used and/or analysed during the current study are available from the corresponding author on reasonable request.

\section{Competing interests}

The authors declare that they have no competing interests

\section{Funding}

Médecins du Monde

\section{Authors' contributions}

NL, CR, NG and AG have participated on the study conception and design. LR, CR, EAF have implemented and coordinated the data collection and analysis. LR, EAF wrote the first article draft. All authors commented on the draft and provided substantial inputs. All authors read and approved the final manuscript.

\section{Acknowledgements}

We are grateful to all the participants of this study for their valuable testimonies. We are also grateful to all volunteers and employees who collaborated in the different stages of the study, and all the collaborators in MdM headquarters (France operations, Health and Advocacy Direction).

\section{Abbreviations}

Cl: Confidence Intervalle

INSERM : Institut national de la santé et de la recherche médicale

IQR : Inter Quartile Range

IRB : Institutional Review Board 
MdM: Médecins du Monde

NGO: Non Governmental Organization

RHS-15 : Refugee Health Screener 15

SD : Standard Deviation

\section{References}

1. Altai Consulting. Mixed migration trends in Libya: Changing dynamics and protection challenges, Altai Consulting in partnership with IMPACT Initiatives, for the UNHCR in Libya, 2017 [Internet]. Disponible sur: http://www.altaiconsulting.com/wp-content/uploads/2017/08/2017_MixedMigration-Trends-in-Libya-Final-Report-Web.pdf

2. UNHCR. Mediterranean Situation [Internet]. Disponible sur: https://data2.unhcr.org/en/situations/mediterranean/location/5205

3. IOM. Four decades of cross Mediterranean. four_decades_of_cross_mediterranean [Internet]. 2019. Disponible sur: https://publications.iom.int/system/files/pdf/four_decades_of_cross_mediterranean.pdf

4. Amnesty International. EU risks fuelling horrific abuse of refugees and migrants in Libya [Internet]. 2016. Disponible sur: https://www.amnesty.org/en/latest/news/2016/06/eu-risks-fuelling-horrificabuse-of-refugees-and-migrants-in-libya/

5. Dollet S. Violence perpetrated in Libya against exiled persons \& consequences on health observed after arrival in Europe A focus on the impact of EU as well as Italian \& French policies. Médecins du Monde; 2018.

6. DMT. Libya - Migrant Report Information Package 18 (March 2018) [Internet]. 2018. Disponible sur: https://www.globaldtm.info/dtm-libya-migrant-report-information-package-18-march-2018/

7. The Refugee Health Screener-15 (RHS-15): development and validation of an instrument for anxiety, depression, and PTSD in refugees. - PubMed - NCBI [Internet]. [cité 7 janv 2020]. Disponible sur: https://www.ncbi.nlm.nih.gov/pubmed/23347455

8. Rights Watch. EU/NATO: Europe's Plan Endangers Foreigners in Libya [Internet]. Disponible sur: EU/NATO: Europe's Plan Endangers Foreigners in Libya

9. Migreurop. Libya. The hounding of migrants must stop [Internet]. Disponible sur: http://www.migreurop.org/IMG/pdf/109697240-Report-Migrants-Libya.pdf

10. Oun AM, Hadida EM, Stewart C. Assessment of the Knowledge of Blast Injuries Management among Physicians Working in Tripoli Hospitals (Libya). Prehospital Disaster Med. juin 2017;32(3):311-6.

11. MSF. Arbitrary detention of refugees, asylum-seekers and migrants must stop [Internet]. 2017. Disponible sur: https://www.msf.org/libya-arbitrary-detention-refugees-asylum-seekers-and-migrantsmust-stop 
12. MEDU. Rapporto sulle condizioni di grave violazione dei diritti umani dei migranti in Libia (20142017) [Internet]. 2018. Disponible sur: http://www.mediciperidirittiumani.org/wpcontent/uploads/2017/12/Rapporto-per-Tribunale-Permanente-dei-Popoli.pdf

13. DRC. Going West. Migration trends from Libya to Europe [Internet]. Disponible sur: https://drc.ngo/media/2846076/going_west_migration_trends_libya_europe_final.pdf

14. Amnesty International. Refugees and migrants fleeing sexual abuse and explotaition in Libya [Internet]. 2016. Disponible sur: https://www.amnestyusa.org/press-releases/refugees-and-migrantsfleeing-sexual-violence-abuse-and-exploitation-in-libya/

15. Freedman J. Sexual and gender-based violence against refugee women: a hidden aspect of the refugee « crisis ». Reprod Health Matters. mai 2016;24(47):18-26.

16. Vu A, Adam A, Wirtz A, Pham K, Rubenstein L, Glass N, et al. The Prevalence of Sexual Violence among Female Refugees in Complex Humanitarian Emergencies: a Systematic Review and Metaanalysis. PLoS Curr. 18 mars 2014;6.

17. Zarocostas J. Libya: war and migration strain a broken health system. Lancet Lond Engl. 03 2018;391(10123):824-5.

18. Crepet A, Rita F, Reid A, Van den Boogaard W, Deiana P, Quaranta G, et al. Mental health and trauma in asylum seekers landing in Sicily in 2015: a descriptive study of neglected invisible wounds. Confl Health. 2017;11:1.

19. Abbott A. The mental-health crisis among migrants. Nature. 13 2016;538(7624):158-60.

20. Bianucci R, Charlier P, Perciaccante A, Lippi D, Appenzeller O. The « Ulysses syndrome »: An eponym identifies a psychosomatic disorder in modern migrants. Eur J Intern Med. juin 2017;41:30-2.

\section{Tables}

Table 1. Sociodemographic characteristics and episodes of different types of violence in Libya by sex: 
SOCIODEMOGRAPHIC

\section{CHARACTERISTICS}

Age in years (Mean, SD)

Level of Education (\%)

Primary

Secondary

Higher

Country of Origin (\%)

Ivory Coast

Mali

Eritrea

Republic of Cameroon

Reasons for leaving country of origin (\%)

Security

Political

Economic

Studies

Type of travel (\%)

Alone

With family

Other

Pregnancy during travel (\%)

Boarding by threat (\%)

Length of stay in Libya in days (median,

IQR)

Healthcare access in Libya (\%)

Need of psychological support after the

survey (\%)

EPISODES OF DIRECT VIOLENCE (\%, CI

95\%)

\begin{tabular}{|c|c|c|c|c|}
\hline Global Violence $^{1}$ & 94,4 & $\begin{array}{r}(89,0- \\
99,9)\end{array}$ & 88,2 & $\begin{array}{r}(71,3- \\
100)\end{array}$ \\
\hline Physical violence & 91,1 & $\begin{array}{r}(84,3- \\
98,1)\end{array}$ & 80,0 & $\begin{array}{r}(57,1- \\
100)\end{array}$ \\
\hline With guns & 76,1 & $\begin{array}{r}(65,6- \\
86,6)\end{array}$ & 53,5 & $\begin{array}{r}(24,7- \\
81,9)\end{array}$ \\
\hline Without guns & 89,5 & $\begin{array}{c}(82,1- \\
97,1)\end{array}$ & 73,3 & $\begin{array}{r}(48,0- \\
98,7)\end{array}$ \\
\hline Violence with deprivation & 89,5 & $\begin{array}{c}(82,1- \\
97,1)\end{array}$ & 86,7 & $\begin{array}{r}(67,7- \\
100)\end{array}$ \\
\hline Detention without food & 88,2 & $\begin{array}{r}(79,3- \\
98,1)\end{array}$ & 86,7 & $\begin{array}{r}(67,7- \\
100)\end{array}$ \\
\hline Detention with racket & 58,8 & $\begin{array}{r}(46,1- \\
71,5)\end{array}$ & 46,7 & $\begin{array}{r}(18,1- \\
75,2)\end{array}$ \\
\hline Detention with ransom & 58,8 & $\begin{array}{r}(46,1- \\
71,5)\end{array}$ & 60,1 & $\begin{array}{r}(31,9- \\
88,0)\end{array}$ \\
\hline Family separation & 37,6 & $\begin{array}{r}(24,2- \\
49,2)\end{array}$ & 46,7 & $\begin{array}{r}(18,1- \\
75,2)\end{array}$ \\
\hline
\end{tabular}

\begin{tabular}{rrrrrrr}
31,9 & SD $(7,4)$ & 30,2 & SD $(7,8)$ & 32,5 & SD $(7,3)$ & 0,27 \\
& & & & & & \\
76,4 & $(55 / 72)$ & 100,0 & $(17 / 17)$ & 69,1 & $(38 / 55)$ & $0,03 *$ \\
18,1 & $(13 / 72)$ & 0,0 & $(0 / 17)$ & 23,6 & $(13 / 55)$ & \\
\hline 5,5 & $(4 / 72)$ & 0,0 & $(0 / 17)$ & 7,3 & $(4 / 55)$ &
\end{tabular}

\begin{tabular}{rrrrrrr}
66,6 & $(48 / 72)$ & 82,4 & $(14 / 17)$ & 61,8 & $(34 / 55)$ & 0,51 \\
23,6 & $(17 / 72)$ & 17,6 & $(3 / 17)$ & 25,5 & $(14 / 55)$ & \\
1,4 & $(1 / 72)$ & 0,0 & $(0 / 17)$ & 1,8 & $(1 / 55)$ \\
\hline 5,6 & $(4 / 72)$ & 0,0 & $(0 / 17)$ & 7,3 & $(4 / 55)$
\end{tabular}

\begin{tabular}{rrrrrrr}
59,7 & $(43 / 72)$ & 82,3 & $(14 / 17)$ & 52,7 & $(29 / 55)$ & 0,12 \\
, 3 & $(11 / 72)$ & 5,9 & $(1 / 17)$ & 18,2 & $(10 / 55)$ \\
& $(6 / 72)$ & 11,8 & $(4 / 17)$ & 25,5 & $(14 / 55)$ \\
\hline 2,8 & $(2 / 72)$ & 0,0 & $(0 / 17)$ & 3,6 & $(2 / 55)$
\end{tabular}

\begin{tabular}{rrrrrrr}
699,4 & $(50 / 72)$ & 41,2 & $(7 / 17)$ & 78,2 & $(43 / 55)$ & $0,01^{*}$ \\
19,4 & $(14 / 72)$ & 35,3 & $(6 / 17)$ & 14,5 & $(4 / 55)$ & \\
11,1 & $(8 / 72)$ & 23,5 & $(4 / 17)$ & 7,3 & $(8 / 55)$ & \\
- & - & 29,4 & $(5 / 17)$ & - & - & - \\
58,1 & $(42 / 72)$ & 47,1 & $(8 / 17)$ & 61,8 & $(34 / 55)$ & 0,68 \\
\hline & $($ IQR 120- & & & & $($ IQR 120- & $0,02^{*}$ \\
180 & $365)$ & 120,0 & $($ IQR 60-180) & 200 & $365)$ & \\
\hline 2,8 & $(2 / 72)$ & 0 & $(0 / 17)$ & 3,6 & $(2 / 55)$ & $0,05 *$ \\
\hline 63,9 & $(46 / 72)$ & 70,8 & $(12 / 17)$ & 61,8 & $(34 / 55)$ & \\
\hline
\end{tabular}

Total $(\mathrm{N}=72) \quad$ Women $(\mathrm{N}=17)$

$\mathrm{p}$
Men $(\mathrm{N}=55) \quad$ value 
Other types of violence

$\begin{array}{rrrrrr}(19,9- & & (9,8- & & (17,5- & \\ 47,5) & 22,2 & 35,6) & 49,1 & 82,1) & 0,03^{*} \\ - & 17,6 & (5,3- & - & - & - \\ & & 29,9) & & & \end{array}$

\section{EPISODES OF WITNESSED}

VIOLENCE (\%, CI 95\%)

\begin{tabular}{|c|c|c|c|c|c|c|c|}
\hline Global Violence $^{1}$ & 100,0 & $(100-100)$ & 100,0 & $\begin{array}{r}(100- \\
100)\end{array}$ & 100,0 & $\begin{array}{c}(100- \\
100)\end{array}$ & - \\
\hline Physical violence & 93,1 & $(85,9-100)$ & 88,2 & $\begin{array}{r}(71,1- \\
100)\end{array}$ & 94,3 & $\begin{array}{c}(87,9- \\
100)\end{array}$ & 0,46 \\
\hline With guns & 87,5 & $\begin{array}{r}(78,7- \\
93,2)\end{array}$ & 82,4 & $\begin{array}{r}(62,1- \\
100)\end{array}$ & 89,1 & $\begin{array}{l}(79,1- \\
99,0)\end{array}$ & 0,52 \\
\hline Without guns & 93,1 & $(85,9-100)$ & 88,2 & $\begin{array}{r}(71,1- \\
100)\end{array}$ & 92,7 & $\begin{array}{r}(83,9- \\
100)\end{array}$ & 0,87 \\
\hline Violence with deprivation & 94,4 & $\begin{array}{r}(89,0- \\
99,9)\end{array}$ & 88,2 & $\begin{array}{r}(71,3- \\
100)\end{array}$ & 96,3 & $\begin{array}{c}(91,3- \\
100)\end{array}$ & 0,21 \\
\hline Detention without food & 87,5 & $\begin{array}{c}(78,3- \\
96,5)\end{array}$ & 88,2 & $\begin{array}{r}(71,2- \\
100)\end{array}$ & 87,3 & $\begin{array}{l}(76,8- \\
97,7)\end{array}$ & 0,93 \\
\hline Detention with racket & 76,4 & $\begin{array}{c}(65,6- \\
87,1)\end{array}$ & 76,4 & $\begin{array}{c}(54,0- \\
99,0)\end{array}$ & 76,4 & $\begin{array}{l}(63,7- \\
89,1)\end{array}$ & 0,99 \\
\hline Detention with ransom & 79,2 & $\begin{array}{c}(68,8- \\
89,6)\end{array}$ & 70,6 & $\begin{array}{c}(46,4- \\
94,7)\end{array}$ & 81,8 & $\begin{array}{l}(70,1- \\
93,6)\end{array}$ & 0,37 \\
\hline Family separation & 61,1 & $\begin{array}{c}(48,9- \\
73,3)\end{array}$ & 52,9 & $\begin{array}{c}(26,5- \\
79,4)\end{array}$ & 63,6 & $\begin{array}{l}(49,5- \\
77,6)\end{array}$ & 0,46 \\
\hline Sexual violence & 79,2 & $\begin{array}{c}(68,8- \\
89,6)\end{array}$ & 82,4 & $\begin{array}{c}(62,1- \\
100)\end{array}$ & 78,2 & $\begin{array}{c}(65,8- \\
90,6)\end{array}$ & 0,74 \\
\hline \multicolumn{8}{|l|}{ Other types of violence } \\
\hline Forced labour & 88,2 & $\begin{array}{c}(79,3- \\
98,1)\end{array}$ & 86,7 & $\begin{array}{r}(67,7- \\
100)\end{array}$ & 88,7 & $\begin{array}{l}(78,3- \\
99,0)\end{array}$ & 0,85 \\
\hline
\end{tabular}

1 The term Global violence refers to physical and/or deprivation and/or sexual violence *p values correspond to two sample T-tests for continuous variables and to Chi-2 tests for categorical values. Values with * are statistically significant $(\mathrm{p}<0.05)$. SD: Standard deviation. IQR: Interquartile range.

Table 2. Episodes of direct physical, deprivation and sexual violence by secondary variables: 


\begin{tabular}{|c|c|c|c|c|c|c|c|c|c|c|c|c|}
\hline \multirow[b]{2}{*}{$(\mathrm{N}=72)$} & \multicolumn{3}{|c|}{ Global violence $^{1}$} & \multicolumn{3}{|c|}{ Physical violence } & \multicolumn{3}{|c|}{ Deprivation violence } & \multicolumn{3}{|c|}{ Sexual violence } \\
\hline & No & Yes & p & No & Yes & $\mathrm{p}$ & No & Yes & $\mathrm{p}$ & No & Yes & p \\
\hline \multicolumn{13}{|l|}{ Sex (\%) } \\
\hline Male & 3,4 & 96,4 & 0,20 & 5,7 & 94 & 0,08 & 15,1 & 84,9 & 0,87 & 81,1 & 18,9 & $0,01 *$ \\
\hline Female & 11,6 & 88,2 & & 20 & 80 & & 13,3 & 86,7 & & 46,7 & 53,3 & \\
\hline \multirow[t]{2}{*}{ Age in years (Mean, SD) } & 30 & 32 & 0,53 & 31 & 31,8 & 0,75 & 32 & 30,5 & 0,61 & 30,7 & 34,4 & 0,71 \\
\hline & $\begin{array}{r}\text { SD } \\
(5,0)\end{array}$ & $\begin{array}{r}\text { SD } \\
(7,6)\end{array}$ & & $\begin{array}{r}\text { SD } \\
(7,0)\end{array}$ & $\begin{array}{r}\text { SD } \\
(8,6)\end{array}$ & & $\begin{array}{r}\text { SD } \\
(6,7)\end{array}$ & SD $(7,9)$ & & $\begin{array}{r}\text { SD } \\
(6,1)\end{array}$ & $\begin{array}{r}\text { SD } \\
(8,6)\end{array}$ & \\
\hline
\end{tabular}

Level of Education (\%)

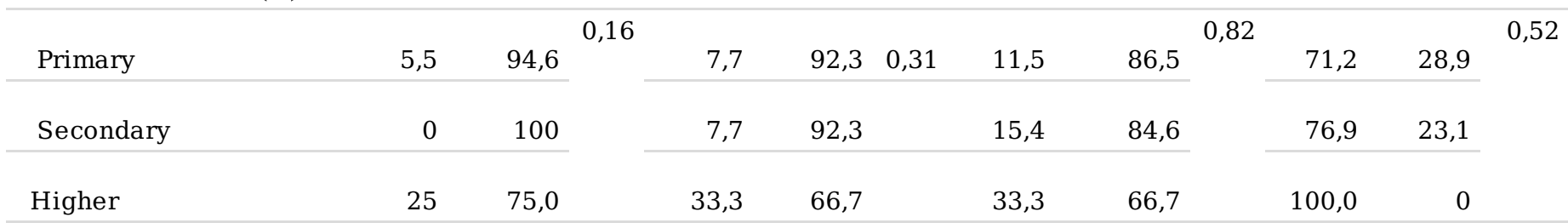

Country of Origin (\%)

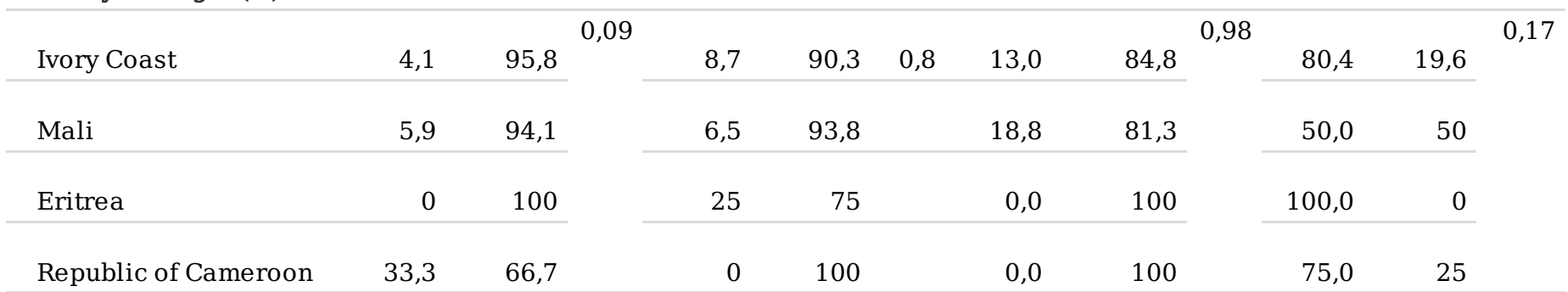

Type of travel (\%)

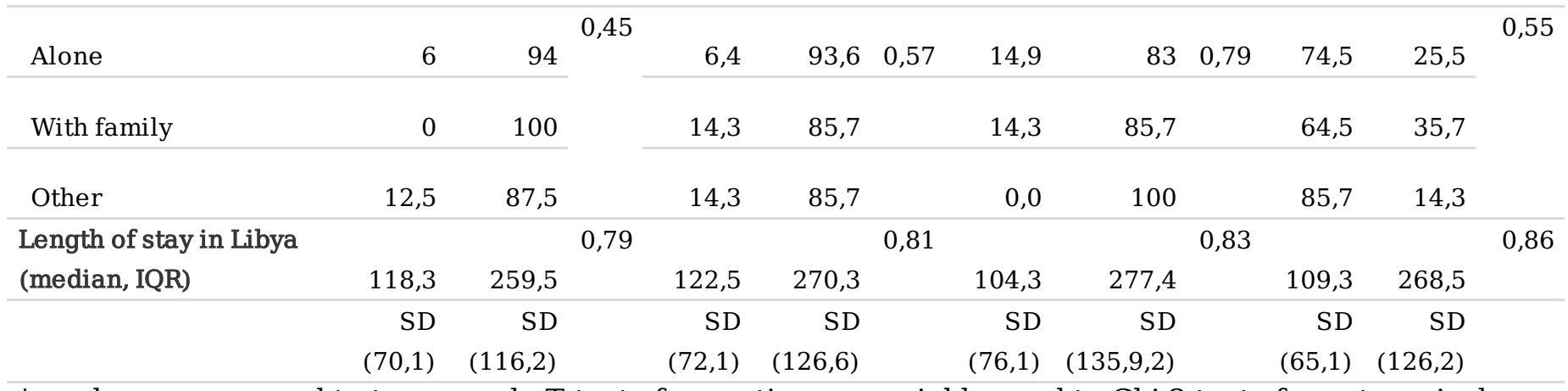

*p values correspond to two sample T-tests for continuous variables and to Chi-2 tests for categorical values. Values with * are statistically significant $(\mathrm{p}<0.05)$. SD: Standard deviation. 